\title{
疾病における脂質代謝ネットワークの機能
}

\section{Functions of Lipid Networks in Disorders}

\section{三木 寿美}

東京都医学総合研究所・生体分子先端 研究分野・脂質代謝プロジェクト

干 156-8506

東京都世田谷区上北沢 2-1-6

Yoshimi MIKI

Lipid Metabolism Project, Department of Advanced Science for Biomolecules, Tokyo Metropolitan Institute of Medical Science 2-1-6 Kamikitazawa, Setagaya, Tokyo 156-8506, Japan

\section{村上 誠}

東京都医学総合研究所・生体分子先端 研究分野・脂質代謝プロジェクト

干 156-8506

東京都世田谷区上北沢 2-1-6

\section{Makoto MURAKAMI}

Lipid Metabolism Project, Department of Advanced Science for Biomolecules, Tokyo Metropolitan Institute of Medical Science 2-1-6 Kamikitazawa, Setagaya, Tokyo 156-8506, Japan
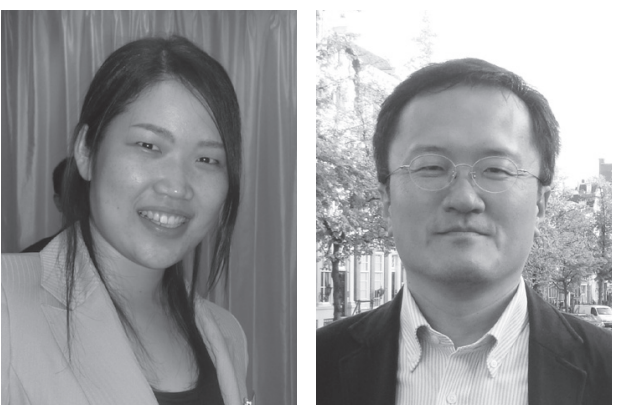

山本 圭

東京都医学総合研究所 ·生体分子先端

研究分野・脂質代謝プロジェクト

干 156-8506

東京都世田谷区上北沢 2-1-6

Kei YAMAMOTO

Lipid Metabolism Project, Department of Advanced Science for Biomolecules, Tokyo Metropolitan Institute of Medical Science

2-1-6 Kamikitazawa, Setagaya, Tokyo 156-8506, Japan

論文要旨：脂質は（1）エネルギー源として，(2) 生体膜の主要構成成分として，(3）シグナル分子とし て生命に必須の生体物質である。脂質メディエーターとは，生体内で合成される脂質分子のうち，細胞外の 刺激によって一過的に生合成される生理活性物質である。ホスホリパーゼ $\mathrm{A}_{2}\left(\mathrm{PLA}_{2}\right)$ は脂質メディエーター 産生の初発酵素であり，膜のリン脂質から脂肪酸とリゾリン脂質を遊離する。脂質メディエーターは生体の 恒常性の維持に寄与する一方で, 炎症・不妊・動脈硬化・癌などの疾病に関与する。本稿では, PLA 2 分子 群によって制御される脂質ネットワークに焦点を当て，いくつかの代表的な疾病との関連について最新の知 見を概説したい。

Abstract: Biological functions of lipids include (1) energy storage, (2) main structural components of cell membranes, and (3) signaling molecules such as lipid mediators. Lipid mediators represent a class of bioactive lipids that are produced locally through specific biosynthetic pathways in response to extracellular stimuli. Their biosynthesis is initiated by release of fatty acids and lysophospholipids from membrane phospholipids by phospholipase $\mathrm{A}_{2}\left(\mathrm{PLA}_{2}\right)$ enzymes. PLA $\mathrm{A}_{2}$ are involved in many physiological processes, and their dysregulations are often linked to various diseases such as inflammation, infertility, atherosclerosis, and cancer. In this article, we will give an overview of recent knowledge of several diseases in which particular lipid networks regulated by $\mathrm{PLA}_{2} \mathrm{~s}$ have critical roles.

Key words: lipid mediator, phospholipase $\mathrm{A}_{2}$, asthma, anaphylaxis, contact dermatitis, infertility

\section{1 はじめに}

脂質はその機能から分類すると大きく 3 つの役割があ る。すなわち, (1)生命活動を営む上で必要なエネルギー

連絡者：村上 誠

E-mail : murakami-mk@igakuken.or.jp
源としての脂質，（2）生体膜の主要構成成分としての脂 質，（3）生理活性作用を持つシグナル分子（脂質メディ エーター）としての脂質である。生体の恒常性の維持や 疾病の発症・増悪・改善にはこれらの機能が密接に関わっ ており，脂質は生体にとって必要不可欠なものである。 脂質メディエーターは，生体内で合成される脂質分子の 
うち，微小環境において特定の代謝経路を通じて生合成 され, 特異的受容体を介して比較的低濃度で生理活性を 示し，速やかに不活性化されるものをいう。エイコサノ イドは最も代表的な脂質メデイエーターであり，医療の 分野でよく利用されている非ステロイド性抗炎症薬 （NSAID）は，エイコサノイドの一群であるプロスタノ イドの生合成の律速酵素であるシクロオキシゲナーゼ （COX）を阻害することで解熱鎮痛効果や抗炎症，抗血 栓などの薬効を示す。

ホスホリパーゼ $\mathrm{A}_{2}\left(\mathrm{PLA}_{2}\right)$ は, グリセロリン脂質の $s n-2$ 位のアシル鎖を加水分解し，脂肪酸とリゾリン脂質 を産生する酵素の一群である。PLA 2 は構造上の特徵や 触媒機構, 局在, 進化的関係から, 細胞内に存在する細 胞質型 $\mathrm{PLA}_{2}\left(\mathrm{cPLA}_{2}\right), \mathrm{Ca}^{2+}$ 非依存性 $\mathrm{PLA}_{2}\left(\mathrm{iPLA}_{2}\right.$ / PNPLA : Patatin（ジャガイモ由来アシル水解酵素） -like phospholipase), 細胞外に分泌される分泌性 PLA ( PLA $_{2}$ : IB, IIA, IIC, IID, IIE, IIF, III, V, X, XIIA，XIIB の 11 種）の 3 つのサブグループに大別さ れる。cPLA $\mathrm{C}_{2}$ の代表格である $\mathrm{cPLA}_{2} \alpha$ はアラキドン酸 （AA）を持つリン脂質に作用し，遊離された $\mathrm{AA}$ は COX やリポキシゲナーゼ（LOX）の作用によってプロ スタグランジン $(\mathrm{PG})$ やロイコトリエン（LT）などの 脂質メディエーターに代謝され，様々な生命応答に関わ る。一方, $\mathrm{sPLA}_{2}$ は, 酵素活性には $\mathrm{mM}$ オーダーの $\mathrm{Ca}^{2+}$ が必要であることから，本質的には分泌された後 に細胞外環境に存在するリン脂質に作用するものと考え
られる。実際, $\mathrm{SPLA}_{2}$ 分子群は細胞膜のみならずリポ 蛋白質やバクテリア膜のリン脂質を基質とする場合があ り，その作用は分子種に固有である ${ }^{1)}$ 。本総説では誌面 の都合上, 既に解析し尽くされた感のある細胞内酵素 $\mathrm{cPLA}_{2} \alpha$ については最小限に留め, 最近見出されてきた 疾患における細胞外酵素 $\mathrm{sPLA}_{2}$ の新しい生理機能につ いて, 脂肪酸由来の脂質メデイエーターの産生との関連 を中心に概説する。

\section{2 呼吸器疾患（気管支喘息）}

気管支喘息はリンパ球，好酸球，マスト細胞などの多 彩な免疫細胞が関与する Th2（Tヘルパー 2 細胞：主 に液性免疫に関与）応答を主体とした気道の慢性炎症で ある。喘息時に産生・放出される生理活性物質には, Th2 サイトカイン（細胞から放出され, 種々の生体反 応を制御する糖タンパク質の総称) - ケモカイン（細胞 を遊走させる活性を持つサイトカインの総称）などの夕 ンパク質性因子の他に，リゾリン脂質から生合成される 血小板活性化因子 (PAF) や AA由来の PG, LT ど の脂質メデイエーターが含まれ, 気道過敏性, 血管透過 性, 粘液分泌, 組織リモデリングなどに様々な影響を及 ぼす。それぞれの脂質メディエーターの喘息における役 割については多くの知見が蓄積しており，Fig. 1 にまと めた。

気管支喘息と $\mathrm{PLA}_{2}$ との関連性を示した研究は 1990 年代から報告されており, 1997 年に $\mathrm{CPLA}_{2} \alpha$ ノックア

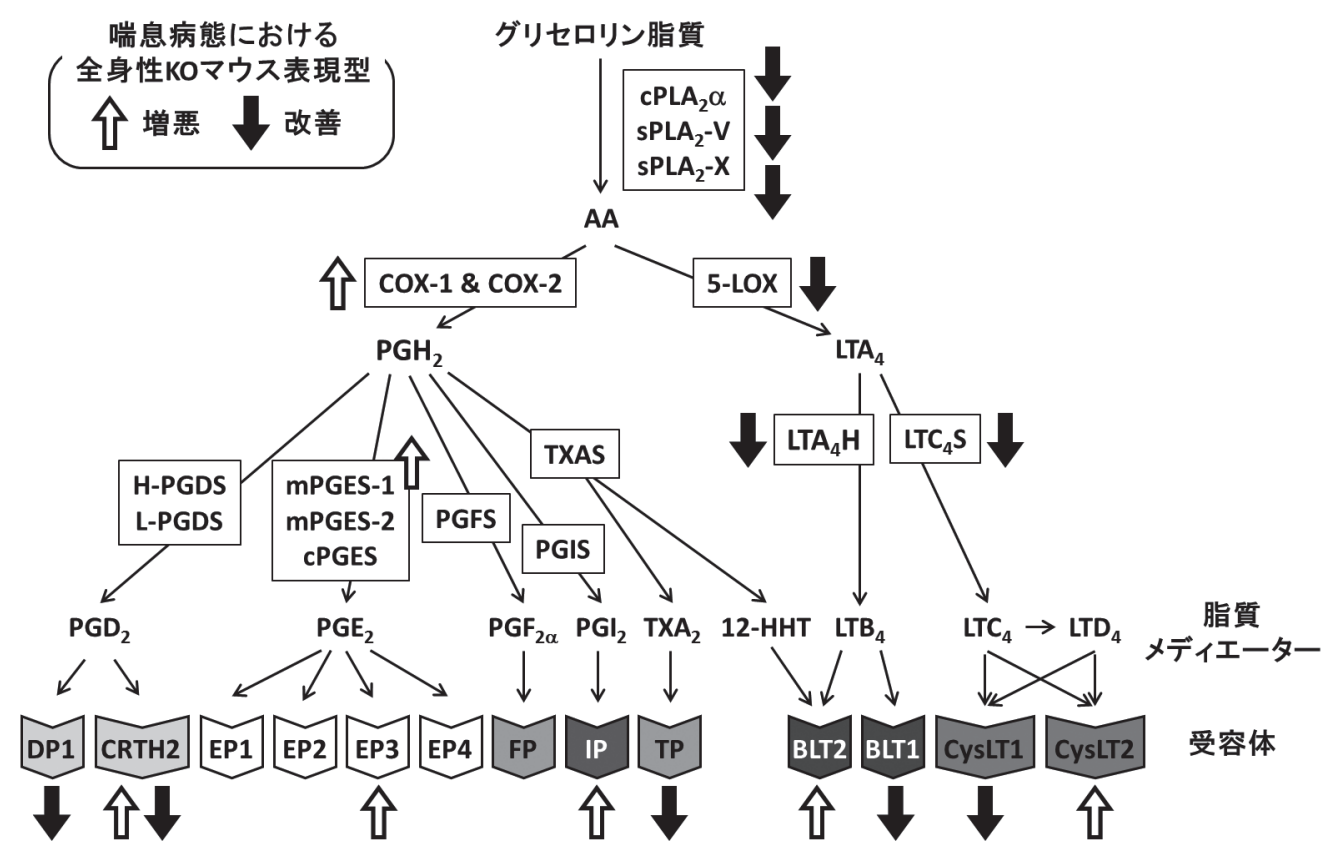

Fig. 1 喘息に扔ける脂質メディエーターの役割。各脂質メディエーター合成酵素および脂質メディエーター受容体の KO マウス における喘息モデルの表現型を示す。合成酵素および受容体の発現細胞の違い，受容体下流のシグナル伝達経路の違いが 表現型に影響すると考えられる。 
ウト $(\mathrm{KO}$; 遺伝子操作による遺伝子欠損) マウスの気 道過敏性が減弱することが示された ${ }^{2)}$ 。 $\mathrm{CPLA}_{2} \alpha \mathrm{KO}$ マ ウスのマクロファージやマスト細胞では PG, LT およ びPAF の産生がほぼ消失する。このことから，喘息応 答に関わる脂質メディエーターは主に $\mathrm{cPLA}_{2} \alpha$ を介して 産生されるものと認識され，他の $\mathrm{PLA}_{2}$ 分子種は長い間 軽視されてきた。

2007 年, $\mathrm{sPLA}_{2}-\mathrm{X} \mathrm{KO}$ マウスに喘息モデルを適用す ると, 炎症細胞の浸潤, 気道過敏性, 浮腫, 粘液分泌, Th2 サイトカイン，およびエイコサノイドが減弱する ことが報告された ${ }^{3)}$ 。喘息を発症したマウスやヒト喘息 患者では，主に気道上皮細胞に $\mathrm{SPLA}_{2} \mathrm{X}$ の発現が認め られる。 $\mathrm{SPLA}_{2}-\mathrm{X} \mathrm{KO}$ マウスにヒト $\mathrm{sPLA}_{2}-\mathrm{X}$ をノック イン（特定の遺伝子を他の遺伝子で置き換え）すると喘 息の病態が再び出現し, ここにヒト $\mathrm{SPLA}_{2}-\mathrm{X}$ 特異的阻 害剂を投与すると症状が改善する ${ }^{4)}$ 。これらの結果は $\mathrm{sPLA}_{2}-\mathrm{X}$ が喘息の促進に関わることを明白に示してい るが, $\mathrm{cPLA}_{2} \alpha$ または $\mathrm{sPLA}_{2} \mathrm{X}$ の単独欠損はそれぞれ 喘息時に誘導されるエイコサノイド産生が正常レベルま で減少するため, 両者が独立して部分的に機能している とは考えにくい。これに関する $\mathrm{sPLA}_{2} \mathrm{X}$ の作用機序と して, 気道上皮から分泌された $\mathrm{SLA}_{2}-\mathrm{X}$ が好酸球の $\mathrm{CPLA}_{2} \alpha$ を活性化して $\mathrm{LTC}_{4}$ を産生する経路が提唱され ているが5)，結論は出ていない。

同じ 2007 年に, $\mathrm{sPLA}_{2}-\mathrm{V}$ KO マウスにおいても喘息 モデルが改善することが報告された ${ }^{6)}$ 。喘息の病態にお いて $\mathrm{sPLA}_{2} \mathrm{~V}$ は気管支上皮細胞と肺胞マクロファージ に発現誘導され, 抗 $\mathrm{sPLA}_{2}-\mathrm{V}$ 抗体を気道に投与すると 気道過敏性が改善する。骨髄移植実験によれば, 免疫細 胞 (抗原提示細胞) と局所環境（気管支上皮細胞）の双 方に分布する $\mathrm{SPLA}_{2} \mathrm{~V}$ が病態の進行に関わる ${ }^{7)}$ 。さら にごく最近, $\mathrm{SPLA}_{2}-\mathrm{V}$ は Th2 サイトカインのインター ロイキン（IL-4）により M2マクロファージに誘導され， $\mathrm{Th} 2$ 免疫応答の促進に関わる「Th2 $\mathrm{sPLA}_{2} 」$ であること が明らかとなった ${ }^{8)}$ 。すなわち, $\mathrm{sPLA}_{2}-\mathrm{V} \mathrm{KO}$ マウスで は Th2 免疫応答自体が減弱し, 血中の免疫グロブリン $\mathrm{E}(\mathrm{IgE})$ レベルが低下する。この表現型は上述の $\mathrm{sP}$ $\mathrm{LA}_{2}-\mathrm{X} \mathrm{KO}$ マウスでは認められず, 両 $\mathrm{sPLA}_{2}$ の機能の 違いを反映する知見といえる。おそらく $\mathrm{sPLA}_{2}-\mathrm{V}$ は免 疫細胞に作用して Th2 応答を促進する何らかの脂質义 ディエーターを産生するものと考えられるが, その活性 本体の同定が待たれる。

$\mathrm{cPLA}_{2} \alpha$ と同様, $\mathrm{sPLA}_{2}$ の機能もまた脂質メディエー ターとの関連で考えられがちであるが, 脂質メディエー ターに非依存的な $\mathrm{sPLA}_{2}$ の作用が気道の病態に関わる 可能性が提唱されている。肺胞の内面には, 肺胞の表面
張力を低下させて肺胞を保護する脂質蛋白質複合体（肺 サーファクタント)が分泌されており, 気道病態で肺サー ファクタントの量が減少すると症状が悪化し, 時に致死 的な重症呼吸器症候群 (ARDS) を導く。肺サーファク タントのリン脂質はほとんどがパルミチン酸を含有する ホスファチジルコリン (PC) であり（総脂質の約 80\%), in vitroでは $\mathrm{SPLA}_{2}-\mathrm{V}$ と $\mathrm{sPLA}_{2}-\mathrm{X}$ の非常によい 基質となる。 $\mathrm{sPLA}_{2}-\mathrm{V}$ トランスジェニック（TG；遺伝 子操作により遺伝子を過剩発現）マウスは, 肺サーファ クタントのパルミチン酸含有 PC が過剩に分解されて肺 胞表面張力が維持できず, 自発呼吸が始まる出生直後に ARDS 様の症状を発症し, 数時間で死亡する ${ }^{9)}$ 。一方で, $\mathrm{SPLA}_{2} \mathrm{~V} \mathrm{VO}$ マウスにARDS モデルを適用すると症状 が軽減することから ${ }^{6)}, \mathrm{SPLA}_{2} \mathrm{~V} \mathrm{~V}$ は病態に伴う肺サー ファクタントの過剩分解に関わるものと考えられる。実 際, 重篤な肺炎患者の気道上皮細胞には $\mathrm{SPLA}_{2}-\mathrm{V}$ の発 現が認められており, $\mathrm{sPLA}_{2}-\mathrm{V}$ は抗体医療の分子標的 として期待される。これに対し, $\mathrm{sPLA}_{2}-\mathrm{X}$ TG マウスは ARDS 様症状を発症せず 9), このことは, 生理的条件下

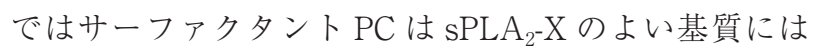
ならないことを示唆している。

\section{I 型アレルギー（アナフィラキシー）}

全身組織に広く分布するマスト細胞は, ヒスタミンな どの多様な炎症性因子を放出してI型アレルギー（アナ フィラキシー）に関わる免疫細胞である。マスト細胞は 主に外界と接する場所, すなわち, 皮膚や鼻腔, 気管支 粘膜，腸管などに広く分布するが，局在する組織によっ て様々なサブグループが存在する。マスト細胞の分化成 熟は, 末梢血中の前駆細胞が各組織に移行（ホーミング） した後に起こる。皮膚や粘膜下組織のような結合組織で 分化したマスト細胞は結合組織型マスト細胞 (CTMC), 粘膜で分化したマスト細胞は粘膜型マスト細胞 (MMC) と呼ばれ, 各成熟マスト細胞の性質は形態的にも機能的 にも異なる。例えば, 脂質メディエーターに関しては, CTMC は主に $\mathrm{PGD}_{2}$ を, $\mathrm{MMC}$ は $\mathrm{LTC}_{4}$ を産生する。組 織中のマスト細胞の増殖・分化・生存には幹細胞因子 (SCF) やその受容体 c-Kit が必須であるが ${ }^{10)}$, SCF だ けではマスト細胞の最終成熟は完全に説明できないこと から, 局所環境由来の他の因子の関与が想定されてい た。最近, 我々は $\mathrm{SPLA}_{2}-\mathrm{III} に よ り$ 産生される $\mathrm{PGD}_{2}$ が マスト細胞の成熟に重要であることを明らかにした ${ }^{11)} 。$

強力なアラフィラキシー誘発因子であるハチ毒には大 量の $\mathrm{SPLA}_{2}$ が含まれており, $\mathrm{SPLA}_{2}$-III はその唯一の哺 乳類ホモログ（配列と機能の似た遺伝子）である。 $\mathrm{SPLA}_{2}$-III はマスト細胞の分泌顆粒に局在しており, 細 


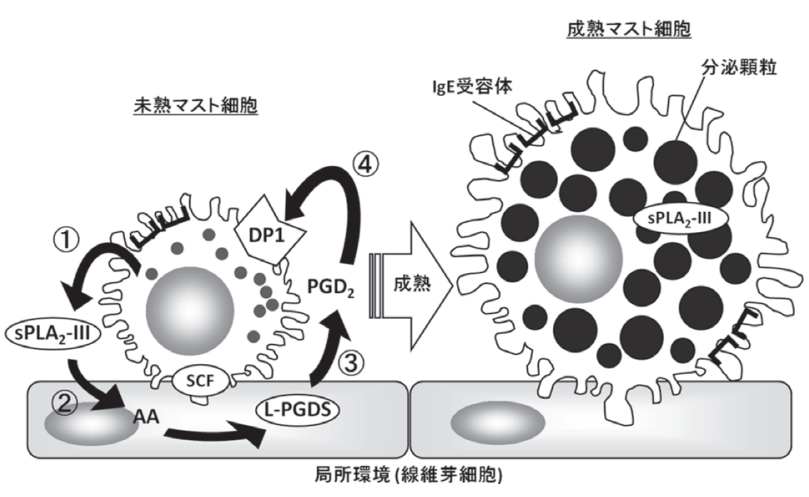

Fig. 2 マスト細胞成熟における Anaphylactic sPLA 2 の役 割。SPLA 2 -III は, (1)局所に定着した未熟マスト細胞 から分泌され, (2)隣接する線維芽細胞に作用して AA を産生し, (3) AA は線維芽細胞の L-PGDS を介 して $\mathrm{PGD}_{2}$ に変換され, (4) $\mathrm{PGD}_{2}$ はマスト細胞の DP1 に作用してマスト細胞の成熟を促進する。

胞の活性化に伴い細胞外に放出される。 $\mathrm{SPLA}_{2}-\mathrm{III} \mathrm{KO}$ マウスにアナフィラキシーを誘導すると, 野生型マウス と比較して症状が著しく減弱する。sPLA 2 -III KO マウ スの皮膚や腹腔のマスト細胞は, 数は正常であるが分泌 顆粒が未発達で，マスト細胞の成熟に関わる分子群（例 えばヒスタミン合成酵素, プロテアーゼ, 造血器型 $\mathrm{PGD}_{2}$ 合成酵素 H-PGDS など）の発現が著しく低い。 $\mathrm{sPLA}_{2}$-III 欠損と同様の表現型は, 局所環境 (線維芽細胞) の $\mathrm{PGD}_{2}$ 合成酵素 L-PGDS, マス卜細胞の $\mathrm{PGD}_{2}$ 受容体 DP1の欠損によってもそれぞれ再現され，共通のマス 卜細胞の成熟不全とアナフィラキシー不応答を生じる。 以上の結果から，（1）sPLA 2 -III は局所に定着した未熟 マス卜細胞から分泌され，(2) 隣接する線維芽細胞に作 用して AA を産生し，（3）AA は線維芽細胞の L-PGDS を介して $\mathrm{PGD}_{2}$ に変換され，(4) $\mathrm{PGD}_{2}$ はマス卜細胞の DP1に作用してマスト細胞の成熟を促進することが明 らかとなった（Fig. 2)。これは, $\mathrm{sPLA}_{2}$ がパラクリン作 用により脂質メディエーターを動員することをin vivo で実証した初めての知見である。したがって，「Anaphylactic $\mathrm{sPLA}_{2} 」$ といえる $\mathrm{sPLA}_{2}-\mathrm{III}$ を特異的に阻害 する薬剤が開発されれば, マスト細胞の関わる様々な疾 患の新たな治療薬として役立つことが期待される。

\section{IV 型アレルギー（接触性皮膚炎）}

抗原曝露により誘発される接触性皮膚炎は典型的な IV 型アレルギー（遅延型過敏症）であり, Th1 応答（T ヘルパー 1 細胞：主に細胞性免疫に関与）を主体とした 獲得免疫応答である。ハプテンなどの抗原の曝露を受け た表皮細胞は TNF- $\alpha$ や IL-1 $\beta$ などの炎症性サイトカイ ンを産生する。その時活性化したランゲルハンス細胞(表 皮の樹状細胞（DC））や真皮 DC は抗原を取り込んで所
属リンパ節へと遊走し，ナイーブ $\mathrm{T}$ 細胞に抗原情報を 提示してメモリー T 細胞へと分化させる $(\text { 感作相 })^{12)}$ 。 再び抗原曝露を受けると, 表皮細胞ではケモカイン産生 が誘導され、メモリー T細胞を速やかに皮膚局所に遊 走させる。この T 細胞は IFN- $\gamma$ などの Th1 サイトカイ ンを産生して炎症を誘導する $(\text { 惹起相 })^{13}$ 。 活性化した $\mathrm{DC}$ は $\mathrm{PGE}_{2}, \mathrm{PGI}_{2}, \mathrm{TXA}_{2}$ を産生し， $\mathrm{PGE}_{2}$ および $\mathrm{PGI}_{2}$ はそれぞれ T 細胞の EP1 および IP 受容体に作用して Th1 応答を誘導する ${ }^{14,15)}$ 。反対に, TXA 2 はナイーブ $\mathrm{T}$ 細胞の TP 受容体に作用して T 細胞と DC の相互作 用を阻害することで免疫応答を抑制する ${ }^{16)}$ 。さらに, $\mathrm{PGD}_{2}$ はP 1 受容体を介して本病態に抑制的に, CRTH2 受容体を介して促進的に作用する ${ }^{17)}$ 。このよう に，脂質メディエーターが接触性皮虐炎の病態に影響を 与えることは明らかであるが，代謝系上流に位置する $\mathrm{PLA}_{2}$ 分子種の実態については不明のままであった。ご く最近, 我々は $\mathrm{sPLA}_{2}$-IID が接触性皮膚炎の「宽解」を 制御する PLA 2 であることを見出した ${ }^{18)}$ 。

$\mathrm{sPLA}_{2}$-IID は二次リンパ組織の DC, 特に活性化前の DC 集団に高発現しており, DCの活性化に伴い発現が 抑制された ${ }^{18)}$ 。 SPLA $_{2}$-IID KO マウスに接触性皮虐炎モ デルを適用すると, 皮膚炎の増悪プロセスは野生型マウ スと同様に進行したのに対し, 寛解期に打ける皮膚肥厚 の減弱が遅延し，これと対応して炎症局所に扮ける IFN- $\gamma$ などの Th1 サイトカインや IL-1 $\beta, T N F \alpha$ などの 炎症性サイトカインが増加していた。この時の KO マウ スの皮膚所属リンパ節では活性化 DC およびエフェク ター T 細胞の割合が増加していたが，制御性 $\mathrm{T}$ 細胞に は変化が見られなかった。また, sPLA - IID KO マウス の骨髄由来 DC（BMDC）は構成的に活性化状態にあり， これをin vitroで抗原刺激した後に野生型マウスに移植 して抗原塗布すると, 野生型 BMDC を移植した群より も皮虐の肥厚が増悪した。接触性皮膚炎モデルを扱って いる過去の論文は惹起相に扔ける皮膚肥厚のピークを評 価する場合がほとんどであり，治癒過程（寛解）の抑制 によることを示した例は少ない。この点において， sPLA ${ }_{2}$-IID KO マウスで見られる表現型はユニークであ り，上記いずれの $\mathrm{PG}$ 受容体の $\mathrm{KO}$ マウスの表現型とも 異なっている。

リピドミクス解析 (質量分析による脂質の網羅的解析) の結果， sPLA 2 -IID KO マウスのリンパ節では $\mathrm{AA}$ ，エ イコサペンタエン酸 $(\mathrm{EPA})$, ドコサヘキサエン酸 (DHA) などの高度不飽和脂肪酸（PUFA）が構成的に減少して いた。このことは， sPLA $A_{2}$ IID が主要発現部位であるリ ンパ節において遊離 PUFA プールの供給に関与してい ることを示している。興味深いことに, 炎症促進性の 
$\mathrm{AA}$ 代謝物（PG，LT 類）の産生は $\mathrm{SPLA}_{2}$-IID の欠損の 影響を受けなかったが, 抗炎症性の 15-deoxy-PGJ $\mathrm{KO}$ マウスで有意に減少していた。さらに，抗炎症性脂 質として知られる EPA や DHA の代謝産物は抗原感作 の有無にかかわらず KO マウスで大きく減少したことか ら, sPLA 2 -IID に依存した遊離 PUFA プールは抗炎症 性脂質メディエーターと選択的に連関しているものと考 えられた。リンパ組織より抽出したリン脂質のリピドミ クス解析の結果，SPLA - IID は主にPUFA を含有する ホスファチジルエタノールアミン $(\mathrm{PE})$ を加水分解し て DHA やAA を遊離することが確かめられた。

以上の結果から, $\mathrm{sPLA}_{2}$-IID は二次リンパ組織の DC に特異的に発現しており, 抗炎症性脂質メディエーター を動員してTh1 免疫応答の寛解に関わる分子種である
ことが明らかとなった（Fig. 3)。 $\mathrm{SPLA}_{2}$ は長い間炎症の 増悪に関わる酵素として認識されてきたが, 本発見は抗 炎症性の機能を持つ「Resolving sPLA $\left.\mathrm{A}_{2}\right\rfloor$ を同定した初 めてのものである。また本成果は, DHA 由来脂質メディ エーターの上流に位置する $\mathrm{SPLA}_{2}$ を初めて同定したも のであり， $\mathrm{sPLA}_{2}$-IID を酵素製荗としたバイオ医薬は新 しい免疫疾患治療法として有望である。

\section{5 生殖 (不妊症)}

脂質は免疫応答のみならず生殖にも深く関与する。例 えば, $\mathrm{PGE}_{2}$ や $\mathrm{PGD}_{2}$ は子宮収縮促進作用があり, $\mathrm{PGF}_{2 \alpha}$ 製剂は妊娠後期の陣痛誘発剂として臨床的に利用されて いる。 $\mathrm{PGE}_{2}$ 受容体のうち, $\mathrm{EP} 2$ の $\mathrm{KO}$ マウスは排卵が 起こりにくく受精率が低下し ${ }^{19,20)}, \mathrm{PGF}_{2 \alpha}$ 受容体 FP の

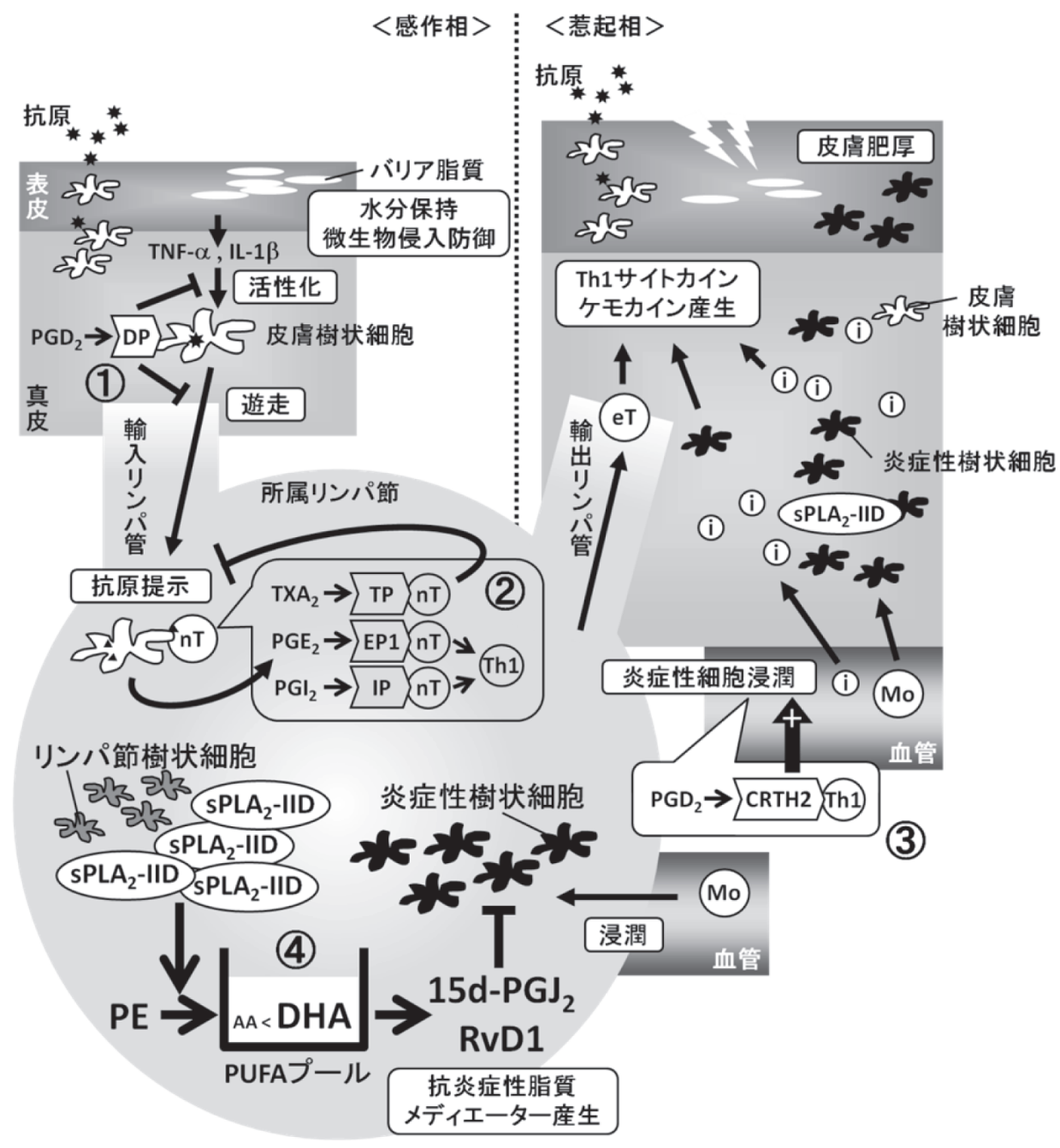

Fig. 3 接触性皮膚炎に扔ける脂質メディエーターとResolving sPLA の役割。皮膚樹状細胞の活性化㧍よび活性化樹状細胞の遊 走は, (1) $\mathrm{PGD}_{2}-\mathrm{DP}$ シグナルにより抑制される。(2) $\mathrm{TXA}_{2}$-TP シグナルは樹状細胞と T 細胞の相互作用を抑制し, $\mathrm{PGE}_{2}-$ EP1 シグナルおよび $\mathrm{PGI}_{2}$ IP シグナルは Th1 細胞分化へ方向づける。(3)炎症細胞（Th1 細胞）の皮膚への浸潤は $\mathrm{PGD}_{2^{-}}$ CRTH2 シグナルにより促進される。(4)リンパ節樹状細胞に発現している sPLA 2 -IID は主に DHA プールの供給を調節し, 抗炎症性脂質メディエーター RvD1の産生を制御して免疫の寛解に関わる。 $\mathrm{nT} ：$ ナイーブ $\mathrm{T}$ 細胞, $\mathrm{eT}$ ：エフェクター $\mathrm{T}$ 細胞, i : 炎症性細胞, Mo : 単球細胞。 
$\mathrm{KO}$ マウスでは分娩が起こらない ${ }^{21)}$ 。また，膜結合型 $\mathrm{PGE}_{2}$ 合成酵素（mPGES-1）の発現は，卵胞細胞におい てゴナドトロピン刺激に伴い COX-2 と同時期に誘導さ れ，COX-1 あるいはCOX-2の KO 雌マウスはそれぞれ いくつかの生殖障害を示す ${ }^{22,23)}$ 。 $\mathrm{CPLA}_{2} \alpha \mathrm{KO}$ マウスが 示す排卵, 着床, 分婏の異常は ${ }^{2)}$, 上記 COX-1，2 や各 種 PG 受容体の KO マウスの表現型と概ね一致すること から, $\mathrm{cPLA}_{2} \alpha$ により産生される $\mathrm{PG}$ 類は雌性生殖に重 要な役割を持つと考えられる。

一方で, PG は精液に大量に含まれるにもかかわらず, $\mathrm{PG}$ 受容体の $\mathrm{KO}$ マウスで雄性生殖異常が見られたとい う報告はない。雄性生殖器は全身組織の中でも特に PUFA が豊富であり，精子膜には DHA やドコサペンタ エン酸（DPA）などの超高度不飽和脂肪酸（VPUFA） が多く含まれる。これらのVPUFA は膜の流動性を高 めることで精子鞭毛に運動性を与えており，精子膜の DHA 含有量と精子運動性は正の相関があることがヒト を含む多くの動物で示されている。精巣には複数の $\mathrm{sPLA}_{2}$ 分子種の発現が認められるが， sPLA 2 -III は精巣 上体頭部の管腔上皮細胞に発現している点で特徵的であ る。我々は, $\mathrm{SPLA}_{2}$-III KO マウスの精巣上体尾部から 採取した精子が，数は正常であるものの運動性が低く， その結果受精率が顕著に減少することを見出した ${ }^{24)}$ 。 精巣上体は精子の成熟に必要な組織であり，精巣で作ら
れた未成熟な精子細胞は精巣上体頭部から精巣上体尾部 に通過する際に成熟して運動能を獲得する。この時，精 子の膜リン脂質にはダイナミックな脂肪酸リモデリング が起こり，オレイン酸（OA）やAA などの不飽和脂肪 酸が DHA やDPA などの VPUFA に置き換わることで 精子は運動性を獲得する。 $\mathrm{sPLA}_{2}$-III KO マウスの精子 ではこの反応が十分に進まず, VPUFA 含有 PCの少な い異常な精子になっていることが分かった。したがって， $\mathrm{sPLA}_{2}$-III は未熟精子の膜リン脂質からの脂肪酸の脱ア シル化反応を触媒しており, $\mathrm{sPLA}_{2}$-III KO マウスでは これが正常に起こらないためにそれに続くDHAや DPAの再アシル化反応が起こらず，成熟精子膜のリン 脂質中のVPUFAが減少したものと考えられる。つまり, $\mathrm{sPLA}_{2}$-III は精巣上体管腔上皮細胞から分泌されて管腔 内を通過する精子膜リン脂質のリモデリングを制御する ことで，精子の成熟に寄与することが明らかとなった

(Fig. 4A)。

精子が卵子と受精するためには，射精により子宮内に 入り込んだ成熟精子が活性化して活発に泳ぎ，卵管で卵 子に出会った際にアクロソーム反応（先体放出反応，精 子の脱顆粒反応）を起こし，卵子膜を取り囲む透明膜を 通過する必要がある。我々は，精子先体部に $\mathrm{SPLA}_{2}-\mathrm{X}$ が発現しており，アクロソーム反応によって分泌される ことを見出した ${ }^{25)}$ 。 $\mathrm{sPLA}_{2}-\mathrm{X} \mathrm{KO}$ マウスの精子はアク

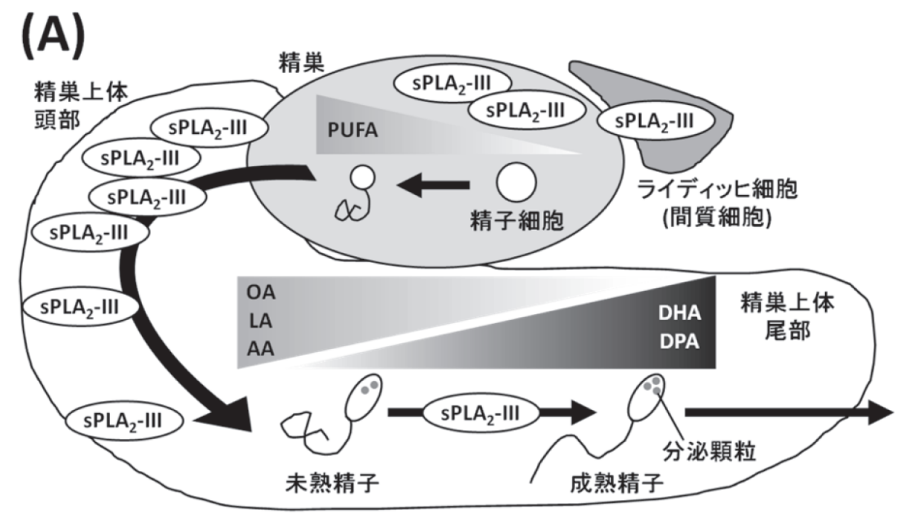

(B)

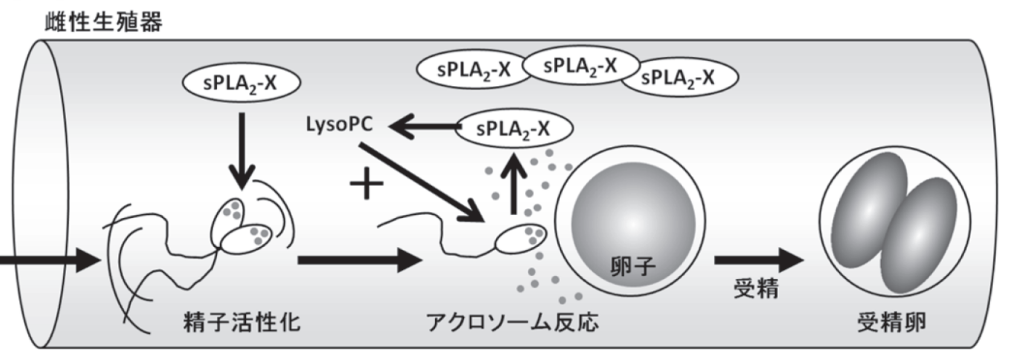

Fig. 4 雄性生殖に扔ける Reproductive sPLA 2 の役割。（A）精巣上体に局在している sPLA ${ }_{2}$-III は精子の脂質リモデリングを制 御することで精子成熟過程を調節する。（B）精子先端部に局在している $\mathrm{sPAA}_{2} \mathrm{X}$ はアクロソーム反応によって分必され， LysoPC を産生して精子の活性化を制御する。 
ロソーム反応が低下しており，卵子との受精率が低下す る。この時, リコンビナント $\mathrm{SPLA}_{2}-\mathrm{X}$ や PC 代謝産物 (リ ゾホスファチジルコリン）を添加すると, KO マウスの 精子の受精率が野生型マウスの精子のレベルまで回復す ることから, $\mathrm{SPLA}_{2}-\mathrm{X}$ は成熟精子の受精段階で精子の 活性化を制御することが判明した (Fig. 4B ${ }^{25)}$ 。一方, $\mathrm{sPLA}_{2} \mathrm{X}$ は子宮内腔上皮細胞や卵子にも発現しており, $\mathrm{sPLA}_{2}-\mathrm{X} \mathrm{KO}$ の雌雄同士を交配させると産仔数が有意に 減少するが, 雄 $\mathrm{KO}$ を野生型の雌と交配しても産仔数に 変化はない。このことは, 䧳側から供給される $\mathrm{sPLA}_{2}-\mathrm{X}$ も生殖に関わることを示唆している。しかしながら, $\mathrm{sPLA}_{2}-\mathrm{X} \mathrm{KO}$ 此性マウスから採取した卵子の体外受精率 は正常であることから, 卵子の $\mathrm{SPLA}_{2}-\mathrm{X}$ は生殖には影 響しておらず，おそらく子宮壁から分泌される $\mathrm{sPLA}_{2}-\mathrm{X}$ が子宮内を通過する精子に作用して精子の活性化を補助 しているものと想定される。

このように, $\mathrm{PLA}_{2}$ は脂質メディエーター産生や脂質 リモデリング反応を制御することで生殖と密接に関わ る。特に $\mathrm{SPLA}_{2}$-III と $\mathrm{sPLA}_{2}-\mathrm{X}$ は, 時空間的に雄性生殖 器の異なるコンパートメントに発現し, 異なるメカニズ ムで精子の成熟と活性化をそれぞれ制御する。これらの $\left\lceil\right.$ Reproductive $\left.\mathrm{sPLA}_{2}\right\rfloor$ は, 不妊症の診断や避妊薬の新 しいターゲットになることが期待される。

\section{6 おわりに}

脂質メディエーターの機能は, その産生酵素と受容体 の遺伝子改変マウス，あるいは特異的阻害剂を用いた多 くの解析によって明らかになりつつあり, その成果の一 部は既に疾病治療に役立っている。脂質メディエーター は特定の生命応答に対して促進的にも抑制的にも作用し 得るが, その産生反応の初発段階を制御する $\mathrm{PLA}_{2}$ 群も 促進的あるいは抑制的に作用することが分かってきた。 本稿で紹介した $\mathrm{sPLA}_{2}$ 群の新しい機能は従来の定説と 必ずしも合致せず，このことは各 $\mathrm{sPLA}_{2}$ 分子種の下流 には未知の脂質ネットワークが隠されていることを暗示 するものである。今後は, $\mathrm{PLA}_{2}$ 群とその下流に位置す る脂質メディエーター合成酵素ならびに受容体の制御機 構が明らかとなり, 各分子の時空間的な脂質代謝ネット ワークの全貌が解明されることで，新たな疾病の創薬 ターゲットが発見されることが期待される。

\section{文 献}

1) Murakami M, Taketomi $Y$ et al., Prog Lipid Res., 50, 152-192 (2011).

2) Uozumi N, Kume K et al., Nature., 390, 618-622(1997).

3) Henderson WR, Jr., Chi EY et al., J Exp Med., 204, 865-877 (2007).

4) Henderson WR, Jr., Oslund RC et al., J Biol Chem., 286, 28049-28055 (2011).

5) Lai Y, Oslund RC et al., J Biol Chem., 285, 41491-41500 (2010).

6) Munoz NM, Meliton AY et al., J Immunol., 179, 48004807 (2007)

7) Giannattasio G, Fujioka D et al., J Immunol., 185, 44304438 (2010).

8) Ohta S, Imamura M et al., J Immunol., 190, 5927-5938 (2013).

9) Ohtsuki M, Taketomi Y et al., J Biol Chem., 281, 36420-36433 (2006).

10) Gurish MF \& Austen KF., Immunity., 37, 25-33(2012).

11) Taketomi $Y$, Ueno $N$ et al., Nat Immunol., 14, 554-563 (2013).

12) Grabbe S \& Schwarz T., Immunol Today., 19, 37-44 (1998).

13) Mori T, Kabashima K et al., J Invest Dermatol., 128, 1719-1727 (2008).

14) Yao C, Sakata D et al., Nat Med., 15, 633-640 (2009).

15) Nakajima S, Honda $\mathrm{T}$ et al., J Immunol., 184, 55955603 (2010).

16) Kabashima K, Murata $\mathrm{T}$ et al., Nat Immunol., 4, 694701 (2003).

17) Yamamoto Y, Otani S et al., Am J Pathol., 179, $302-$ 314 (2011).

18) Miki Y, Yamamoto K et al., J Exp Med., 210, 1217-1234 (2013).

19) Kennedy CR, Zhang $Y$ et al., Nat Med., 5, 217-220 (1999).

20) Tilley SL, Audoly LP et al., J Clin Invest., 103, 15391545 (1999).

21) Sugimoto Y, Yamasaki A et al., Science., 277, 681-683 (1997).

22) Gross GA, Imamura T et al., Proc Natl Acad Sci US A., 95, 11875-11879 (1998).

23) Lim H, Paria BC et al., Cell., 91, 197-208 (1997).

24) Sato H, Taketomi $Y$ et al., J Clin Invest., 120, 14001414 (2010)

25) Escoffier J, Jemel I et al., J Clin Invest., 120, 1415-1428 (2010). 